\title{
FARM TOURISM ACROSS EUROPE
}

\author{
Irma Potočnik-Slavič ${ }^{1}$, Serge Schmitz ${ }^{2}$
}

Received 11 December 2012; Accepted 12 April 2013

\begin{abstract}
Based on evidence from nine countries (UK, Belgium, France, Germany, Italy, Poland, Croatia, Slovenia, and Ireland), this special issue analyses the fabrics of farm tourism in Europe. It identifies two main development trends: on one hand, a small scale and dispersed activities, at the other hand a product in response to tourist market demand. A brief overview of existing farm tourism practices in the European rural areas indicated an interesting interface between the forms and dimension of farm tourism embeddedness in local environment and at the same time, the ways and range of internationalization of farm tourism business.
\end{abstract}

Keywords: farm tourism, agritourism, European rural areas, rural tourism, embeddedness, local impact, new peasantry, farm diversification, niche tourism.

\section{Introduction}

Since the income gained directly from agriculture has been decreasing in the framework of continuing reform of the EU Common Agricultural Policy, farmers and other members of farm households have to look for additional income sources. This has been most pronounced in the $E U$ in the form of diversification of farm family income arising from activities performed either off- or/and on-farm. With reference to the latter, there is evidence of both new "farming « and new »non-farming " activities (Brandth and Haugen, 2011, 35) which may lead farmers away from traditional farm culture and ways of life. Amongst several forms of on-farm diversification, agritourism is often indicated as having »development « potential for farms and rural areas. Specifically, it is expected that agritourism should promote employment, generate additional revenue, promote sustainable stability in rural communities, and also contribute to a well managed cultural landscape.

There is a rich body of literature on agritourism, based mostly on individual case studies, but there is an obvious lack of international comparisons. Based on evidence from nine countries (UK, Belgium, France, Germany, Italy, Poland, Croatia, Slovenia, and Ireland) we have been able to identify two general development trends in agritourism:

- the contemporary prevalence of small scale and dispersed agritourism businesses that are operated mostly by farm family members on active farms on one hand (Lampič, 2012; Potočnik Slavič, 2012; Cigale, 2012; Perpar, 2012; Udovč, 2012; Jurinčič and Kerma, 2012; Marsat 2012; Lübke, 2012);

\footnotetext{
${ }^{1}$ Dr. Irma Potočnik-Slavič, Assistant Professor, Department of Geography, Faculty of Arts, University of Ljubljana, Aškerčeva 2, SI - 1000 Ljubljana, Slovenia, e-mail: irma.potocnik@ff.uni-lj.si.

2 Dr. Serge Schmitz, Professor, Department of Geography, Laplec, Faculty of Sciences, University of Liege, Allee du 6 Aout, B - 4000 Liege, Belgium, e-mail: s.schmitz@ulg.ac.be.
} 
- on the other hand, there is evidence of progressive separation from agricultural
activities where the agritourist firm is penetrating into the (local/regional/national/international) tourist market, by offering a product in response to demand (Ciervo, 2012; Talbot, 2012; Sznajder, 2012, Cawley, 2013) and more pronounced forms of concentrated tourism are becoming obvious (Marsat, 2012, Lukić, 2012, Dubois and Schmitz, 2012).

The above mentioned trends in agritourism are quite different, not just in terms of organization, scale, attitudes, expectations, but especially from the perspective of their impacts. The empirical surveys that were presented at the occasion of the international Smart conference on agritourism (»Agritourism between Embeddedness and Internationalization«; Medana, Slovenia, June 2012) supported a diverse range of case studies, but also a range of mixed or hybrid situations and structures. Some of the most relevant findings and comments outlined on the occasion of the above event are discussed in this special issue of European Countryside.

It may seem futile to pay attention to this marginal practice both from a tourism and an agricultural point of view, yet it a worthwhile activity for those families, who diversified into agritourism and found in this way the possibility of maintaining life on the farm. Agritourism contributes to maintain a regional heritage as well as a family heritage and is a window to look forward to a new peasantry in many underprivileged rural areas.

\section{Agritourism: Part of the New Peasantry}

A review of the agritourism related literature reveals an abundance of empirical studies, whereas there are fewer theoretical contributions that address the concept(s) of agritourism. This concept remains vague applied by scientists and is used and misused in marketing. Nevertheless, some concepts may be discussed which are relevant to the scope of our research. Because we acknowledge both the importance of the geographical context for these issues and the richness of benchmarking against international experience, our discourses aim to underline and to understand original agritourism practices in relation to their spatial context. According to Sznajder et al. (2009) attention has to be paid to the historical structure of the economy, the state of farming, the demographic situation, accessibility to markets, social attitudes, and capital resources. Therefore the farm structure, the available labour force and buildings, capital resources as well as the physical and cultural contexts (including landscape features, natural and cultural heritages) comprise the main characteristics. In the era of globalization, both local embeddedness and internationalization of agritourism must be addressed.

The prevailing concept of agritourism is still generally related to the resilience strategy of the single farm. Resilience thinking offers a framework to emphasize dynamics and interdependencies across time, space and domains. It is based on understanding socioecological systems as complex and future developments as unpredictable and thus emphasises adaptive approaches to farm management. In practice, this would mean focusing on the factors that build the ability of the farm to respond to change (Darnhofer, 2009).

Most farm tourism businesses are family businesses on family operated farms. In family businesses, decisions depend on the family life-cycle concept: i. e. on family relationships, lifestyles, property, as well as commercial considerations of growth and profit (Ollenburg and Buckley, 2007); and these issues are equally relevant for family farm tourism business. Despite economic pressures, family farms persist because of ties between family and land. Inheritance issue are key and include: the ability of the landholding to support multiple generations simultaneously, choice of heir, financing retirement of older generations and transfer of equity to younger generations, transfer of management control. Farm tourism may be one way to generate supplementary income to retain family farmland and lifestyle. Farm tourism may also have social goals. Rural families have a tradition of hospitality, irrespective of income considerations. Different farm tourism operators (full-time farm tourism operators, part-time farmers, retirement farmers, lifestyle farmers) may therefore respond very differently to government programs and incentives. 
The concept of "the new peasantries" was developed by Van der Ploeg (2008) who reinstates peasantry as a theoretically meaningful concept, and argues that it describes processes of agricultural restructuring in developed as well as in developing countries. The process of repeasantization (with endogenous and local dimensions) is characterized by three elements: use of the farm resource base, autonomy and value adding. Old and neglected resources are rediscovered, highlighting the continuity of past, present and future. Autonomy is perceived as strengthening the farms' resource base without making them dependent upon financial and industrial capital. Value added both on the farm level and in the sector as whole progresses through the creation of new, additional income. Repeasantization redefines the farm from being limited to the production of raw materials only, into a multi-product enterprise with many new ways of relating between society and nature. Therefore, contemporary farmers are reconstituting themselves as »new peasants«. As is stated in a recent Norwegian study (Brandth and Haugen, 2011), one might expect farm tourism and agriculture to give rise to various identities according to the degree of the involvement in agritourism. The authors conclude that in their study, agritourism has revitalized farms that otherwise might have been abandoned, and that farm identities are carried on, albeit in ways that are multiple and have various meanings.

The fourth concept could be referred as commodification of farm assets according to the wishes and expectations of farm tourism visitors. The early incursion of the consumption economy into rural areas simply created new opportunities for enhanced exchange values to be attached to objects whose use value for production has declined (Woods, 2011). For example, farms started to obtain additional income by converting disused outbuildings into holiday accommodation, on turning fields into paying campsites. At the moment, we are facing the society of simulacrum which implies the consumption of rural signifiers that have become wholly detached from a materially embedded rurality and exist purely as a virtual or hyper-rural designed exclusively for consumption. Examples might include staged performances of farm work, farm parks, shopping villages etc. Mitchell $(1998,2009)$ describes this cycle as 'creative destruction'. There are opportunities for the re-commodification of traditional food and drink products, and of traditional systems of production and consumption of food and drink. This movement has promoted the sale and consumption of local food in rural areas - for example through farmers markets, higher prices (via PDO, PGI) have been attained. This recommodification of food and drink as signifiers of rurality or of regional identity for food tourism has become a common strategy for farm diversification, as part of the development of farm tourism (examples can include opening of farm shops selling produce directly to the visitors, pick-your-own fields for fruit and vegetables, on-farm restaurants, farm and vineyard tours, observation rooms, museums, displays of production process, farm open days, on-farm accommodation which promises the chance to eat home-grown regional cuisine. However, the commodifacation of existing practices, places and events for tourist consumption introduces changes: restaurants get larger, less informal, tourist plates are introduced, farmers have switched to new products or production methods that replicate regional traditions (Woods, 2011).

\section{Comparison of Distinctive Agritourism Practices Across the Europe}

Agritourism remains a complex subject of study with many definitions depending on regions, legislative systems, and authors (Dubois and Schmitz, 2012a). Labels such as 'agritourism', 'farm tourism', 'farm-based tourism' and 'rural tourism' are often used interchangeably with agritourism and each other, but have also been used explicitly to denote similar but distinct concepts. The result is a confusing picture, especially when authors do not clarify why they have used one particular term rather than another (Phillip et al., 2010). Consequently, the mentioned authors have developed a typology for defining agritourism which builds on three key areas of debate in the literature: whether the product is based on a "working farm «, the nature of contact between the tourist and agricultural activity, and the degree of authenticity in the tourism experience.

At the occasion of the international Smart conference we were also able to identify the different understanding of agritourism in nine European states. Whilst the Mediterranean tradition is 
more keen on agritourism, it is the Anglo-Saxon practice to refer more frequently to farm tourism; but in practice there is also a term tourism on the farm (when the environment and the essence of the farm are an integral part of the product, for example: help with work on the farm, tractor rides, harvesting, farm stays; Marsat, 2012). Dubois and Schmitz (2012b) have underlined the opposition of "agritourism" and "tourism on the farm" definitions when passing from a tourist perspective to an agricultural perspective. We would like to underline, however, that it was not the aim of the conference to develop new definition of agritourism

We were able to notify several common characteristics of farm tourism in selected European countries.

(1) In all case study areas, the contribution of agritourism to the general tourist market is quite modest either from the perspective of total income, number of farm tourism properties or number of overnight stays. A report from Wales (Talbot, 2012) provides some grounds for optimism because, despite the current financial austerity, the evolving tourist demand, steady tourist expenditure and government strategy all suggest that there are still opportunities to be had from tourism and leisure development.

(2) Because the legislation relating to farm tourism is distinctively different in all surveyed countries (very loose in Belgium on one hand, and quite strict in Slovenia), there still does not exist a common understanding and operational definition of farm tourism at an EU level.

(3) Also there are several common traits relating to the motivation for establishing farm tourism: the wish to gain stable income on the farm, the prudent use of existing farm capital stocks and potentials, to mention the most frequent ones; the pursuit of socialization may complete the picture.

(4) All surveyed farm tourism businesses reported on difficulties in balancing the main income activity (being agriculture or other off-farm diversification) with agritourism. Therefore, in some rural areas (as in France and Belgium) they are practising tourist activities which demand less personal contact with the farm family (e. g. self catering apartments called "gîtes").

(5) All farm tourism holders reported on continuous changes in tourist demand and the need to follow new trends.

(6) New means of communication, mostly web portals and central registration systems, brought farm tourism closer to a wider market. Thus, the farmers are very aware of positive (more visitors, higher occupancy rate, etc.), but also of negative effects (a high fluctuation rate, commissions for services provided by central registration system, tourist have no ideas or information on the essence of farm tourism, etc.), to mention only a few.

(7) Uniqueness, authenticity, attractiveness and personal contact have been repeatedly exposed as the major advantages of farm tourism in comparison to other forms of tourism.

(8) Intimate links with nature were also pointed out as a major trump for farm tourism development.

On the other side, there are numerous differences amongst the surveyed countries: below we indicate several characteristics and trends for proper understanding of current farm tourism practices. We must point out that the participants at the Smart conference analysed relatively marginal regions from an agricultural point of view: Apulia, Croatia, Massif Central, Saarland, Slovenia, Wales, Wallonia, and western Ireland.

The research on Welsh farm tourism included "proactive farmers « who were identified (WRO, 2010; quoted in Talbot, 2012) as: generating multiple income streams, possessing entrepreneurial skills, being open to new ventures and embracing environmental responsibility. Proactive farmers and their tourism businesses involved in the case study were not an average sample of farm tourism enterprises in Wales. Talbot (2012) reports that in Wales many farm 
tourism entrepreneurs have responded to the expectations of nostalgic tourists, for example by providing accommodation in scenic surroundings and by gentrifying their farms by removing activities that might spoil the tourist experience of the countryside. This is clear evidence which confirms the concept of agriculture as a commodification of farm assets is often taking place in practice.

In Wallonia, agritourism began officially in 1976, but the developments are quite modest. A non-profit association "Accueil champêtre en Wallonie" especially promotes this tourist activity. The contemporary situation indicates that this association targets its promotion on the diversity of Walloon landscapes and proposes stays and accommodation in a rural environment. Their activity has been broadened (since the number of farm tourism premises is modest) by inclusion of private B\&B and apartments in rural areas. In 2012, officially, about 380 agritourist tenants were involved in agritourism, proposing gîte (self catering apartment) in a majority of cases, bed and breakfast and camping on the farm. But this represents only $3 \%$ of all Walloon farmers. In recent years, more emphasis has been given to different activities that a visitor can do on the farm (thematic activities, education, activities linked to local products, rental of large rooms for special events; the farmer usually combines several activities).

In Slovenia, where small and fragmented agricultural holdings prevail, searching for additional income has a long and strong tradition. There are approx. 370 farms offering accommodation (with total of 4342 tourist beds in 2010), another 412 are operating mostly during week-end offering food and beverages (Cigale, 2012). In wine-growing regions there have been several wine tourism routes established (since 1992) and there are representative wine-cellars (Jurinčič and Kerma, 2012) consisting of a backbone of enogastronomic tourism and rural development. Rational and commercially interesting has been a specialization of farm tourism into several categories (family friendly, children friendly, etc.) amongst them also are strongly marketoriented organic farms which gain income from farm tourism activity. Lampič confirms (2012) that these are more innovative farm households and market oriented, i. e. they have similar characteristics as the surveyed Welsh farm tourism holders (characterised as "pro-active farms «; Talbot, 2012). Since farm tourism has to be legally registered as supplementary activity on the farm, we have some data on its development. For example: in the last decade there was more emphasis put on 'hard' infrastructural farm tourism investments (new apartments, seats, etc., Potočnik Slavič, 2012); in the last five years there has been a switch to more financially modest 'soft' farm tourism infrastructure (mostly non-gastronomy services: farm visit, demonstration of farm work, hire of sports equipment, horse riding, rides with traditional horse pairs, rental of picnic sites; Register of Supplementary Activities on Farms, 2011). The great majority of farm tourism enterprises are either closely or quite weakly connected to the Association of Farm Tourism in Slovenia which provides accurate information about and promotes accommodation and other tourist relevant services (via an internet portal catalogue in five languages; Čuček and Kosi, 2012) and is strongly connected to the nation-wide network of the agricultural advisory service with approx. 40 specialized consultants for supplementary onfarm activities (Vodopivec Rozman, 2012). There have been some examples where agritourism activity became so strong that it prevailed over farming, but on the other hand there are also farms the sustainability of whose income improved only because of farm tourism activities (Potočnik Slavič, 2012).

Also in Italy, agritourism was born as a spontaneous form of hospitality and then it developed as a tightly connected and complementary activity to the main activities of cultivation, forestry and breeding. Since 1990 it has undergone a gradual and progressive separation from agriculture; also relevant is corporatization in management (Ciervo, 2012). Based on research in Apulia, there are 357 authorised agritouristic farms, 201 of which have other activities (55 horse riding, 19 touring, 6 nature watching, 71 trekking, 94 offering mountain biking, 45 courses, 19 offer sport activities, 11 educational farms, 88 various activities; ISTAT, 2010). Agritourism offerings share a strong identity image and a continuous reference to the territorial features with an offer of modern services that frequently recall typical urban cultural values (comfort, relaxation, entertainment, privacy). In reality, two types of agritourism co-exist: (genuine) agritourism and commercial agritourism. The most recent national law stimulates commercial agritourism, while the connection with agriculture becomes progressively weaker. 
Evidence confirms (Ciervo, 2012) that in Apulia agritourism is spreading due to a business investment choice rather than a real agricultural income diversification choice.

In Ireland, farm tourism was encouraged in the 1960s to compensate for the shortage of hotel accommodation and was aimed initially at tourists from the United States and Britain (Cawley, 2013). External demand shapes supply as much or more than the internal resources of the farm. Today the increase in visitors who hike and walk in the Irish countryside offers new opportunities which remain to be developed. With some exceptions of individual businesses and successful local community tourism initiatives, Irish agritourist services have not established a critical mass to support their own marketing. (Cawley, 2013).

In Croatia, before the transition to a market economy, there were officially only a few tourist farms. The Croatian Farmers Union provided one of the first stimuli for farm tourism development; by mid 1990s Croatia had legislation which recognized farm tourism. The latest research (2011) registers 886 farms with accommodation and other leisure-oriented activities with two strong littoral clusters (in Istria and Dubrovnik-Neretva County). These data do not mirror the real situation: there are many more farms practising tourism, accommodation and other leisure activities (indicated by the Agricultural Census in 2003, there were 4506 farms of this type). Many of them (located in 538 settlements) are not »working farms « or they do not produce for the market. Their promotion also seems inadequate, although some counties have their own catalogues directed to rural and farm tourism. The majority of these farms are located in littoral counties, which are mostly areas with a strong concentration of tertiary sector jobs forming the core of Croatian tourism. Other settlements of this type are also located in greater number in the vicinity of some nature protected areas in the continental part of Croatia. Lukic (2012) reports on poor human and social capital hindering farm tourism development in peripheral types of rural areas.

Special insight into agritourist structure has been attained in the case of a UNESCO biosphere reserve in Bliesgau (Saarland, Germany; Lübke, 2012). Biosphere reserves are considered as model regions for sustainable development in which relations between men and the environment represent the focal point of research and development, where biosphere reserves pursue a balance between protection and utilization. In addition to its protective function, agritourism is a key element in the development functions of biosphere reserves. Agritourism providers are offered individual advice regarding structural requirements for rooms and holiday flats, theme-oriented development on farms, and successful targeting of customers. Agritourism is characterised by undisturbed recreation and a variety of experience opportunities concerning agriculture. Since the number of farms has fallen sharply in recent decades, horse rearing has become an important branch of agriculture. This fact confirms that besides protection the process of strong commodification of special, protected natural and cultural landscapes is taking place.

In France, in general the quantitative importance of agritourism among the population of farmers $(2.8 \%$ of the whole in 2000$)$ is very limited, if one does not include the direct selling of products. In the Auvergne, the Regional institution wanted to help farmers more efficiently to find more revenue and/or employment via diversification in agritourism (Marsat, 2012). Currently, 600 farms offer accommodation, catering and leisure activities and 1500 farms sell some products directly on the farm. Marsat (2012) argues that better cooperation between networks (Gîte de France-Auvergne, Accueil paysan, etc.) is needed.

\section{The Current Interplay of Embeddedness and Internationalization in the Case of Farm Tourism}

A brief overview of existing farm tourism practices in the European countryside indicated an interesting interface between the forms and dimension of farm tourism embeddedness in local environment and at the same time, the ways and range of internationalization of farm tourism business. 


\subsection{Embeddedness of Farm Tourism}

As rural economies become more complex, locally based small-sized and medium-sized enterprises are playing a larger role in economic development. Recent studies of rural entrepreneurship have been strongly influenced by the new regionalism literature, which focuses primarily on place-based social and economic attributes (such as inter-firm networks, embeddedness, institutional thickness and untraded interdependencies; Young, 2010). One of the most valuable findings from both a policy and theoretical standpoint is the significance of business networks and embeddedness to the success of rural firms (e.g. DERREG project, 2011). This research suggests that businesses that are well-networked and well-integrated into local customs, institutions and 'identities and symbolic activities' (Cawley et al., 2007) are better able to access help, co-ordinate activities and collectively pursue opportunities than less wellembedded firms (Johannisson et al., 2002). In rural studies, globalisation-induced restructuring in traditional agricultural and resource sectors caused significant attention to be paid to the emergence of a consumption countryside, whereby the fate of rural regions becomes increasingly tied to consumptive activities (such as tourism, organic foods and ex-urban lifestyle migration) rather than production activities alone (Marsden 1999).

According to the aims of above mentioned conference, we mostly tried to address the following questions: "How are economic, social and environmental impacts of agritourism mirrored on the local level? How is agritourism connected to other local economic activities? How is agritourism influencing local tourism development? Is agritourism successful in revitalisation of rural areas? What are the positive and negative implications of agritourism on the local community?" These questions are especially important in the case of agritourism because farm tourism starts most of the time from the existing family farms and have then to deal with the existing local and regional context (Cigale et al., 2013, Ciervo, 2012, Dubois and Schmitz, 2012a, Talbot, 2012). Farms have to valorise the local assets and take care of natural, social and cultural heritage. We would like to emphasize that no common methodology to assess the level/stage of embeddedness was elaborated. We took mostly an empirical approach on the basis of evidence in the surveyed rural areas; therefore more qualitative observations prevail. Nonetheless, these studies provide interesting insights and raise important questions that this special issue brings to the attention of the academic community.

In the case of the local impact of agritourism (on the environment and on socio-economic organization) Ciervo (2012) argues that the genuine agritourism (tight agricultural connection, local culture, rural lifestyles, coincidence between economic and territorial interests) would be a mean to resist the standardising power of global markets, the commodification of culture, the homogenisation of places and behaviours. But if rural traditions and cultural heritage are used mainly as an attractive factor to compete on the market it can contribute to a higher territorial impact and above all to destroy gradually the soul of place. In fact, commercial agritourism aims to increase revenue in the short-middle term by the basic means that is competitiveness, regardless of socio-cultural, landscape and environmental costs. Commercial agritourism loosing its links with agriculture seems doomed in the middle/long time to failure, its main goals being to support the rural world that is used as a mere factor of production. To evaluate the local impact of agritourism it is crucial to evaluate its relations with environment and society, its independence of external sources and its ecosystem weight, according to use and quantity of energy, water, and material sources. Agritourism on one hand needs new equipped spaces and on the other hand, it implies an increasing use of water and energy, in addition to waste production. Projects adopted as an ideal model (zero environmental impact and closed loops) are those, where the resources needed for the development of the activities are internal and the wastes produced are reused, if possible, as an input to other productive processes. In the biosphere reserve Bliesgau in Germany (Lübke, 2012) there are ecological traffic plans or the provision of environmentally oriented services (e-bikes for example); also organic farms with gastronomy services are to be taken into the consideration (Lampič, 2012). Ciervo (2012) underlines that commercial agritourism can produce a remarkable impact on territorial socio-economic organization and it influences further agriculture marginalization, through "transformation" of the farmer into a business man, the removal of land from agricultural use, urbanization of the rural lifestyle, and thus cultural homogenisation. All this produces 
a deconstruction of traditional relations and contributes to damage the role of rural areas and small towns.

There are several examples where agritourism is supporting local/regional tourism development. In the case of wine tourism routes (WTR) which are mostly based on marketoriented wine-growing active farms, Jurinčič and Kerma (2012) assert that there are localities with very mature offerings: they usually follow the family tradition, are close to foreign markets, but usually they are relatively small-scale private farms and wineries. "Fine dining or gourmet restaurants (sometimes registered also as agritourism; Jurinčič and Kerma, 2012) with protected food products, hiking paths/walkways (Perpar, 2012), bike routes, special events, wine festivals and accommodation reflecting region's character" actively contribute to local tourism services in the Primorska wine region (Slovenia)". Also the designers of local and regional development plans share the opinion that the WTR represent a backbone of rural development, which however needs to be upgraded with authentic events and festivals. The task of local authorities and tourist organizations, together with the associations of wine makers, is to motivate suppliers (i. e. farmers) by grading and awarding them. It is also vital to combine the WTR offer with other forms of tourist services in rural areas, by organizing daytrips or longer travel packages. Wine festivals and events are in general well visited; however the majority of the visitors (especially to traditional events) are locals and day visitors. Also in Wales farm tourism is supporting the survival of rural communities and aids in their regeneration. Evidence from a study (Talbot, 2012) suggest that successful and community oriented (creating economic linkages and providing community facilities) farm tourism enterprises can have a positive impact on rural communities economically, socially, culturally and environmentally. On the other hand, evidence from Croatia (Lukić, 2012) - where mostly tourism in continental rural areas (especially farm tourism) has been marginalised - confirm that farm tourism is not comprehensively used as a potential tool for regional development since there are few settlements with registered farm tourism in the rural periphery.

\subsection{Internationalization of Farm Tourism Business}

This segment is focused on a broader agritourism perspective, i. e. what is the position of agritourism in the existing and emerging tourism sector? Several issues were addressed: "IS agritourism a niche market? Is agritourism supplementary, complementary or competing with other forms of tourism? How are changing demands in tourist markets influencing agritourism development? What kind of geographic settings are influencing agritourism development? How is globalisation affecting the uniqueness of agritourism?" Since there is a lack of common methodology, some issues gained more and some less attention.

Dubois and Schmitz (2012a) state that agritourism is a niche market in Wallonia, Belgium since it comprises a connection between the tourist and the agricultural network. Tourists are more and more interested in new forms of tourist products. Many tourists can be attracted to farm tourism because they are offering other attributes, e. g. those important in the context of outdoor recreational activities, and - additionally- a peaceful environment (in many cases far away from tourist crowds), healthy food, etc. (Cigale, 2012). In Wallonia different rules from the administrative and political spheres reinforce this niche agritourist market and it is probably a guarantee against transformation into an extreme form of agritourism closer to mass activities. Moreover agritourism is often located in places where there is no other possible service, or no service at the same price. An agritourism niche market does not develop without any risk; the (over)improvement of tourist infrastructure and thematization of the farm might distort the former idea of agritourism. Ciervo (2012) cited numerous reasons for agritourism choices that cover almost all the segments of the demand.

Agritourism can be seen as a complementary activity; it does not offer strong competition to hotels, but it is competitive with some other types of establishment. Agritourism concerns a particular type of tourist profile (mostly young families with children, children as a part of school group, groups of friends, urban people, trying to find rural roots (Cigale, Lampič, Potočnik, 2012; Dubois and Schmitz, 2012). In France, some destinations of rather concentrated tourism may include agritourism offers. The latter benefit from a rich tourism context, but suffer from negative externalities in their agricultural activities. Tourism in return, 
benefits from this type of diversification (Marsat, 2012). It is evident that only those events, festivals and agritourism activities in rural areas which are based on originality and authenticity will prosper in the future.

\section{Conclusions and Future Perspectives of Agritourism Development and Research}

The Smart conference focused on several important issues relating to contemporary agritourism development in Europe; also new research fields were addressed. The participants with their empirical evidence strongly support the following recommendations.

1. The necessity of networking of actors/stakeholders on various levels.

2. Complementary development of local/regional/national tourist infrastructure, supply and promotion.

3. Agritourism brand should be defined more clearly because of the current confusion with rural tourism resulting from a non-distinctive tourist product.

4. There is a future for agritourism if the links with agricultural activities are maintained.

Further research in agritourism is required, particularly towards developing a comprehensive methodology to assess the real impact of agritourism on rural communities.

References

[1] Brandth, B., Haugen, M. (2011). Farm diversification into tourism - Implications for social identity? Journal of Rural Studies 27 (1), pp. 35-44.

[2] Cawley, M., Marsat, J. B. \& Gilmor, D. A. (2007). Promoting Integrated Rural Tourism: Comparative Perspectives on Institutional Networking in France and Ireland, Tourism Geographies 9 (4), pp. 405-420.

[3] Ciervo, M. (2012). Agritourism in Italy and the local impact referring to Itria Valley. The organic firm "Raggio Verde" and its ecological agritourism project. In: Agritourism Between Embeddedness and Internationalization. Proceedings, pp. 11-26.

[4] Cigale, D. (2012). Farm tourism in the context of Slovenian tourism. In: Agritourism Between Embeddedness and Internationalization. Proceedings, pp. 27-32.

[5] Čuček, V. \& Kosi, R. (2012). Association of tourist farms of Slovenia - example of joint market approach. In: Agritourism Between Embeddedness and Internationalization. Proceedings, pp. 28.

[6] Darnhofer, I. (2009). Strategies of family farms to strengthen their resilience. Presented at the $8^{\text {th }}$ International Conference of the European Society for Ecological Economics, June 2009 in Ljubljana (Slovenia), pp. 10.

[7] DERREG project ( 2011). http://www.derreg.eu/ (10. 9. 2012).

[8] Dubois, C. \& Schmitz, S. (2012a). What is the position of agritourism on the Walloon tourist market? In: Agritourism Between Embeddedness and Internationalization. Proceedings, pp. 33-43.

[9] Dubois, C. \& Schmitz, S. (2012b). Un touriste à la ferme: de la thématisation au simulacre. L'expérience touristique, $4^{\mathrm{e}}$ édition des Rendez-vous Champlain sur le Tourisme 21-23 Mai 2012, Bruxelles: Université Libre.

[10] Johannisson, B., Ramirez-Passilas, R. \& Karlsson, G. (2002). The institutional embeddedness of local inter-firm networks: a leverage for business creation. Entrepreneurship \& Regional Development 14(3), pp. 297-315. Doi: $10.1080 / 08985620210142020$. 
[11] Jurinčič, I. \& Kerma, S. (2012). Wine tourism routes as backbone of agritourism development in the Primorska Region. In: Agritourism Between Embeddedness and Internationalization. Proceedings, pp. 44-57.

[12] Lampič, B. (2012). Sustainable Agriculture and Agritourism - A New Perspective for Rural Slovenia (pp. 58-59). In Agritourism Between Embeddedness and Internationalization. Proceedings.

[13] Lübke, S. (2012). Local impacts of agritourism in the biosphere reserve Bliesgau. In Agritourism Between Embeddedness and Internationalization. File of papers, pp. 60-66.

[14] Lukić, A. (2012). Agritourism and Plurality of Rurality: Case Study of Croatia (pp. 67). In: Agritourism Between Embeddedness and Internationalization. Proceedings.

[15] Marsat, J.-B. (2012). Which need of knowledge for designing a regional policy for agritourism, at the junction of two domains? The case of Region Auvergne (France) (pp. 68-83). In Agritourism Between Embeddedness and Internationalization. Proceedings.

[16] Marsden, T. (1999). Rural futures: the consumption countryside and its regulation. Sociologia Ruralis, 39(4), 501-520. Doi: 10.1111/1467-9523.00121.

[17] Mitchell, C. J. A. (1998). Entrepreneurialism, commodification and creative destruction: a model of post-modern community development. Journal of Rural Studies, 14(3), 273-286. Doi: 10.1016/S0743-0167(98)00013-8.

[18] Mitchell, C. J. A. \& de Waal, S. B. (2009). Revisiting the model of creative destruction: St. Jacob's, Ontario, a decade later. Journal of Rural Studies, 25(1), 156-167. Doi: 10.1016/j.jrurstud.2008.09.003.

[19] Ollenburg, C. \& Buckley, R. (2007). Stated Economic and Social Motivations of Farm Tourism Operators. Journal of Travel Research, 45(4), 444-452. Doi: $10.1177 / 0047287507299574$.

[20] Perpar, A. (2012). Walkways as an initiator of rural and farm tourism - The case of Community of Trebnje (pp. 84-87). In Agritourism Between Embeddedness and Internationalization. Proceedings.

[21] Phillip, S., Hunter, C. \& Blackstock, K. (2010). A typology for defining agritourism. Tourism Management, 31(6), 754-758. Doi: 10.1016/j.tourman.2009.08.001.

[22] Potočnik Slavič, I. (2012). Future Agritourism Development in Slovenia: Farmers' Perspective (pp. 88-92). In Agritourism Between Embeddedness and Internationalization. Proceedings.

[23] Register of Supplementary Activities on Farms (2011). Ministry of Agriculture and Environment.

[24] Sznajder, M., Przezborska, L. \& Scrimgeour, F. (2009). Agritourism. Wallingford: CABI.

[25] Sznajder, M. (2012). Green tourism - global phenomenon (p. 12). In Agritourism Between Embeddedness and Internationalization. Proceedings.

[26] Talbot, M. (2012). Farm Tourism in Wales: Products, markets and evidence of local benefits (pp. 93-106). In Agritourism Between Embeddedness and Internationalization. Proceedings.

[27] Udovč, A. (2012). Model of a vital tourist farm (pp. 107-111). In Agritourism Between Embeddedness and Internationalization. Proceedings.

[28] Vodopivec Rozman J. (2012). Regulations on agritourism - critical perspective (pp. 30-31). In Agritourism Between Embeddedness and Internationalization. Proceedings.

[29] Woods, M. (2011). Rural. Abingdon and New York: Routledge. 